\title{
Mowing rights-of-way affects carbohydrate reserves and tiller development
}

\author{
HISHAM R. NOFAL, RONALD E. SOSEBEE, CHANGGUI WAN, JOHN BORRELLI, RICHARD ZARTMAN, AND \\ CYNTHIA MCKENNEY
}

Authors are Research Associate, Professor; and Research Associate, Dept. of Range, Wildlife, and Fisheries Management, Texas Tech Univ.; Professor, Dept. of Civil Eng.; Professor, Dept. of Plant and Soil Science, Texas Tech Univ., Lubbock, Tex. 79409; and Assistant Professor and Urban Horticulturist, Texas A\&M Univ., Dallas, Tex. 75252.

Abstract

Intensive mowing has contributed to the loss of some climax grasses in Texas highway rights-of-way. The overall objective of this study was to evaluate the effect of different mowing heights and frequencies on total non-structural carbohydrate (TNC) concentration and tiller density in short and mid-grasses grown along highway rights-of-way. Shortgrasses were represented by blue grama [Bouteloua gracilis (H.B.K) Lag ex Steud.], and midgrasses were represented by silver bluestem [Bothriochloa saccharoides (Sw.) Rydb], both of which are indigenous species. During 1999 and 2000, grasses were either non-mowed (control) or subjected to mowing heights of 5 and $10 \mathrm{~cm}$, and 5 mowing frequencies (monthly, bi-monthly, tri-monthly, 1-time-only at the beginning or end of the growing season). Plants of both species mowed less frequently at either stubble height had higher TNC concentrations than plants subjected to more frequent mowing. Mowing produced fewer $(P<0.05)$ tillers after 2 consecutive mowing seasons than after 1 mowing season in silver bluestem. Silver bluestem tiller growth was more susceptible to frequent mowing than blue grama. Mowing during periods of rapid inflorescence development reduced tiller density in both species after 2 mowing seasons. Mowing height and frequency guidelines are proposed to maintain roadside grasses in their most productive state through planning mowing practices around the target plant's natural growth habit and it's ability to respond to defoliation.

Key Words: Defoliation, total non-structural carbohydrates (TNC), blue grama, (Bouteloua gracilis), silver bluestem, (Bothriochloa saccharoides)

Grasses along highway rights-of-way live in a harsh environment because of the time, frequency, and height of annual mowing. Consequently, many native, late-seral grasses are absent from the rights-of-way.

The major premise for measuring carbohydrate reserves is to provide an index of potential regrowth based on the concept that carbohydrates provide the major source of carbon or energy. Plants that replenish reserves rapidly after emergence and growth, thereby, minimizing the portion of the growing season with low

The Texas Dept. of Transportation is gratefully acknowledged for support of this research. This manuscript is Contribution No. T-9-931 of the College of Agricultural Sciences and Natural Resources, Texas Tech Univ., Lubbock, Tex. 79409.

Manuscript accepted Feb. 04.

\section{Resumen}

La siega intensiva ha contribuido a la pérdida de algunos zacates clímax en los derechos de vía de los caminos de Texas. El Objetivo general de este estudio fue evaluar el efecto de diferentes alturas y frecuencias de siega en las concentraciones totales de carbohidratos no estructurales (TNC) y la densidad de hijuelos de zacates cortos y medianos que crecen a lo largo de los derechos de vias de las carreteras. Los zacates cortos fueron representados por el "Blue grama" [Bouteloua gracilis (H.B.K) Lag ex Steud.] y los zacates medianos por "Silver bluestem" [Bothriochloa saccharoides ( $\mathrm{Sw}$.) Rydb], ambos son zacates nativos. Durante 1999 y 2000 los zacates se sometieron a los siguientes tratamientos: no segados (control) y segados a 5 y $10 \mathrm{~cm}$ de altura y a 5 frecuencias de siega (mensual, bimestral, trimestral y una sola siega al inicio o al final de la estación de crecimiento). En ambas especies las plantas segadas menos frecuentemente, a cualquier altura de siega, tuvieron concentraciones más altas de TNC que las plantas sujetas a siegas mas frecuentes. En "Silver bluestem" la siega consecutiva durante dos estaciones produjo menos $(P<\mathbf{0 . 0 5})$ hijuelos que la siega en una estación. El crecimiento de los hijuelos de "Silver bluestem" fue más susceptible a la siega frecuente que el "Blue grama". Después de dos años la siega durante el periodo de desarrollo rápido de la inflorescencia se redujo la densidad de hijuelos de ambas especies. Se proponen guías de altura y frecuencia de siega para mantener a los zacates presentes a lado de las carreteras en su estado más productivo a través de planear las prácticas de siega en base al hábitat natural de crecimiento de las especies de interés y su capacidad para responder a la defoliación.

reserve status, are least affected by defoliation and recovered rapidly following severe defoliation (Menke and Trlica 1981, 1983, Richards and Caldwell 1985).

Leaf area available for photosynthesis after defoliation often determines the amount of TNC synthesis and rate of leaf regrowth (Briske and Richards 1995, Coyne et al. 1995, Mullahey et al. 1990, Dahl and Hyder 1977, White 1973). Defoliation to short stubble heights often leads to greater reduction in non-structural carbohydrates in stem bases. However, with higher stubble heights, non-structural carbohydrate concentrations increased in the stem bases of big bluestem (Andropogon gerardii Vitman; Forwood and Magai 1992). Blue grama [Bouteloua gracilis (H.B.K) Lag ex Steud.] plants defoliated 3 times at moderate or heavy intensity had greater stem-base TNC 
levels than non-defoliated plants (Buwai and Trlica 1977a, 1977b). Increasing number of clippings reduced TNC levels in crowns of blue grama (Menke and Trlica 1983).

The effects of defoliation height and frequency on tiller initiation are difficult to generalize, and it is easily confounded with phenological development and seasonal progression of environmental variables (Briske and Richards 1995). Scheduling the frequency and degree (stubble height) of defoliation could affect reproductive growth and regeneration of new tillers (Hyder 1972).

Our objectives were to study the effects of mowing height and frequency on carbohydrate reserves and tiller density for 2 indigenous grasses that grow along highway rights-of-way. Specifically, the objectives were: 1) to evaluate seasonal TNC trends in basal crown and stem bases of mowed and non-mowed blue grama and silver bluestem [Bothriochloa saccharoides (Sw.) $\mathrm{Rydb}$ ], and 2) to determine the effects of height and frequency of mowing on over-time TNC concentration and tiller density. The null hypothesis tested was: height and frequency of mowing would not have an effect on seasonal TNC and tiller density in either grass.

\section{Materials and Methods}

\section{Study site}

This research was conducted on the Southern High Plains of Texas. Two locations were chosen, 1 in Crosby County and 1 in Lynn County. The Crosby County site, which represented the blue grama study site, is located about 3 to $5 \mathrm{~km}$ north of U.S. Highway $62 / 82$ about $4 \mathrm{~km}$ east of Crosbyton, on Farm Road 259 (33 $33^{\circ} \mathrm{N}$, $\left.101^{\circ} 14^{\prime} \mathrm{W}\right)$. Precipitation was $32.4,62.4$, and $41 \mathrm{~cm}$ in 1998, 1999, and 2000, respectively, $80 \%$ of which occurred May through September. The long-term average precipitation of the area is $57 \mathrm{~cm}^{\text {year }}{ }^{-1}$ $\left(\mathrm{NOAA}^{\mathrm{l}}\right)$. Elevation is about $917 \mathrm{~m}$. The dominant soil of the surrounding area is a Mansker-Potter complex. The Mansker soil (Fine-loamy, carbonatic, thermic Calcidic Paleustoll) comprises $55 \%$ of the complex and is predominantly a fine sandy loam. The Potter soil (Loamy-skeletal, carbonatic, thermic Petronodic Ustic Haplocalcid) comprises about $20 \%$ of the complex and is predominantly a shallow loam. The dominant vegetation along the

'NOAA: National Oceanic and Atmospheric Administration roadside and the mixed plains range site adjacent to the right-of-way include blue grama and sideoats grama (Bouteloua curtipendula (Michx.) (Koos et al. 1966).

The Lynn County site, which represented the silver bluestem study site, is located about 8 to $11 \mathrm{~km}$ west of Tahoka on U.S. Highway $380\left(33^{\circ} 10^{\prime} \mathrm{N}, 101^{\circ} 47^{\prime} \mathrm{W}\right)$. Precipitation was 30,48 , and $50 \mathrm{~cm}$ in 1998, 1999, and 2000, respectively, most of which occurred May through September. The long-term average precipitation of the area is $50 \mathrm{~cm}_{\text {year }}{ }^{-1}$ (NOAA). Average elevation is about $949 \mathrm{~m}$. The dominant soil of the surrounding area is an Amarillo fine sandy loam (Fine-loamy, mixed, superactive, thermic Aridic Paleustalf; Mowery and McKee 1959). Silver bluestem is the dominant species along the highway rightsof-way.

Experimental plots at each study site were established in a linear arrangement along the chosen highway rights-of-way. Plots were chosen based on visual stand homogeneity of the selected species to minimize variability. Each plot was $25 \mathrm{~m}$ long and $3 \mathrm{~m}$ wide.

\section{Defoliation treatments}

Treatments included a non-mowed control, 2 mowing heights of 5 and $10 \mathrm{~cm}$, and 5 mowing frequencies; repeated mowing at monthly, bi-monthly, or tri-monthly intervals throughout the growing season, and mowed 1-time-only at the beginning or 1-time-only at the end of the growing season. Treatments were imposed midMay through mid-October of 1999 and 2000. Plots were mowed using a 2-wheel, height-adjustable lawn mower pulled by an All Terrain Vehicle.

\section{TNC analysis}

Total non-structural carbohydrate concentrations were measured in 3 randomly collected plants per plot for each treatment. Samples were collected at 30-day intervals from May 1999 through November 2000. Three plants from the control plots were also collected monthly from October 1998 through November 2000.

Grass samples (including shoots and roots) were collected, immediately placed on ice in the field, and transported to the lab for chemical analysis. Samples were dried in a forced-air oven at $60^{\circ} \mathrm{C}$ for 72 hours. Roots were dissected from the basal crown and stem bases of the plants and discarded. The stem base, including the lower 2 to $2.5 \mathrm{~cm}$ of the stem, and the basal crown were dissected from the rest of the shoot material (which was also dis- carded), ground to pass a $0.5-\mathrm{mm}$ USA Standard Testing Sieve, and stored in amber vials until chemical analyses were run.

Concentrations of TNC were determined by the acid hydrolysis method as described by Murphy (1958). One halfgram plant samples were boiled for 2 hours in $60 \mathrm{ml}$ of $0.2 \mathrm{~N} \mathrm{HCl}$ and then fil. tered through No. 2 Whatman filter paper into volumetric flasks. Distilled water was added to bring the volume of the filtrate up to $100 \mathrm{ml}$. An aliquot $(1 \mathrm{ml})$ of the fil. trate was extracted and mixed with $4 \mathrm{ml}$ of distilled water. A $1 \mathrm{ml}$ aliquot was then pipetted into a test tube to which $10 \mathrm{ml}$ of anthrone reagent was added. After heating for 15 to 20 minutes at $97^{\circ} \mathrm{C}$, the TNC concentration was measured spectrophotometrically (absorbance) at $612 \mathrm{~nm}$.

All samples were referenced with glo. cose standards solutions. Carbohydrate concentrations were estimated by comparing each sample to the glucose standards at a known concentration (standard curve). Aliquots from duplicate samples were analyzed for each sampling date. The TNC concentration (\%) for each plant sample was calculated as follows:

$$
\operatorname{TNC}(\%)=\left[\frac{\text { Absorbance }}{0.27}\right] \times 100
$$

\section{Tiller density}

Tiller density was estimated withir three, $0.25 \mathrm{~m}^{2}$ quadrats per plot once in February 1999 (after 1 mowing season and again in November 2000 (after? mowing seasons). Tillers were counted it each $0.25-\mathrm{m}^{2}$ quadrat and were reported as tillers $\mathrm{m}^{-2}$.

\section{Data presentation and statistical analysis}

Seasonal TNC trends were described for each treatment in both species. Treatments were subjected to a split-plot arrangement with a factorial completely randomized design in a repeated measures analysis. Mowing heights and frequencies constitut ed the main plots. Time of mowing (month) constituted the subplots. Each treatment was randomly assigned to 3 replicates.

Analyses of variance were performed to detect differences among and/or within treatment means for each species. Mean separation using least significant difference (LSD) was performed to test differences among treatment means of main and significant interaction effects. 


\section{Results and Discussion}

\section{Total non-structural carbohydrates}

During 1999 and 2000, similar TNC patterns were observed in the stem bases and crowns of non-mowed control plants of blue grama and silver bluestem. Carbohydrates were depleted during quiescence or dormancy, growth initiation, and early vegetative stages occurring in early spring, but were replenished during later vegetative stages in spring and autumn (Fig. 1 and 2).

The TNC tended to be greater during the active growing period with mowing at either 5-or 10-cm stubble height for blue grama and silver bluestem than with no mowing. Carbohydrate concentrations were substantially reduced by increased frequency of mowing in both species. Consequently, as frequency of mowing decreased and rest periods (length of time between mowing periods) increased, TNC concentrations increased (Fig. 1 and 2). Blue grama results are explained by the work of Buwai and Trlica (1977a, 1977b) who reported that blue grama plants remain in a semi-dormant state during defoliation, thus maintaining adequate TNC levels, while non-clipped control plants utilized their stored TNC for growth. This was evidenced by sharp declines in TNC in non-clipped plants in the spring (Fig. 1). Silver bluestem TNC results could be explained by the findings of Coyne et al. (1995) who stated that the increase of TNC levels in the defoliated over non-defoliated plants is due to the removal of the upper portion of the canopy that allows for more light penetration that enhances photosynthetic capacity of lower leaves. Since the lower leaves were in the proximity of the crown, the crown TNC levels would be replenished more quickly by the enhanced photosynthesis of lower leaves.

\section{Tiller density}

Blue grama

After 1 mowing season, plants mowed at the 10-cm stubble height produced more $(\mathbb{P}<0.05)$ tillers than plants mowed at the 5 -cm stubble height. Plots mowed 1-timeonly at the beginning of the season produced the greatest $(P<0.05)$ tiller numbers compared with plots subjected to all other mowing frequencies (Table 1).

Tiller density measured after 2 mowing seasons resulted in significant height $x$ frequency interaction $(\mathrm{P}<0.05$; Table 2$)$. Mowing at $5-\mathrm{cm}$ stubble height monthly produced more tillers than mowing bimonthly, tri-monthly, and 1 time only at
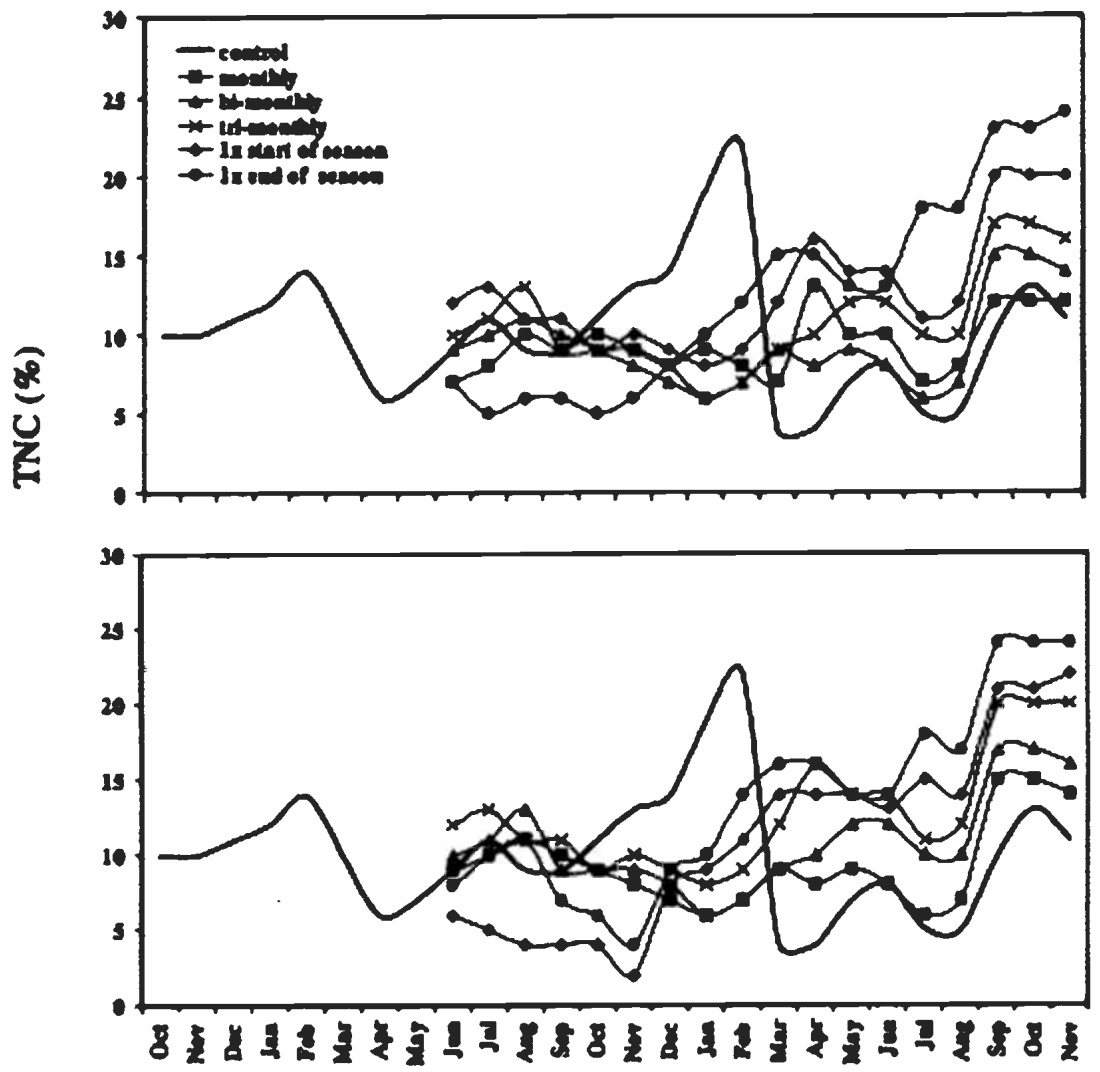

Issi

Iss

200

\section{Date}

Fig. 1. Basal crown and stem base TNC trends for blue grama in the control and at the $5-\mathrm{cm}$ (top) and at the 10-cm (bottom) mowing height at different mowing frequencies.

the end of season $(\mathrm{P}<0.05)$. This suggests that blue grama can withstand a considerable defoliation as has been recently reported by Eneboe et al. (2002). The inconsistency in tillering responses to mowing height in blue grama during the first and second growing season is not well understood: Similar pattern was observed in little bluestem (Schizachyrium scoparium) (Butler and Briske 1988). It is interesting to note that after 2 consecutive years of clipping, plants mowed at $10-\mathrm{cm}$ stubble bi-monthly or 1-time-only at the end of the growing season produced greater (Table $2, \mathrm{P}<0.05$ ) number of tillers than the other mowing treatments including the $5-\mathrm{cm}$ monthly mowing. Non-mowing control also had greater number of tillers than the other mowing treatments except 1 -time-only at the end of season $(P<0.05)$. No mowing $x$ year interaction $(P>0.05)$ was detected during the study period.

Despite being defoliation resistant, the highest tiller densities were observed in the $10-\mathrm{cm}$ stubble mowing treatments and the non-mowing control in blue grama (Table
2) when evaluated over 2 growing seasons. This may be attributed to greater tiller recruitment and lower tiller mortality at the higher stubble height defoliation as reported in weeping lovegrass (Eragrostis curvula) (Wan and Sosebee 2002). Caraco and Kelley (1991) pointed out that the smaller parental tillers often abandon their daughter

Table 1. Mean tiller density for blue grama at different mowing heights and frequencies after 1 mowing season.

\begin{tabular}{lc}
\hline \hline Mowing Treatment & Tiller Density \\
\hline Mowing height & (Tiller $\mathrm{m}^{-2}$ ) \\
Non-mowed & $238 \mathrm{~b}^{1}$ \\
$5 \mathrm{~cm}$ & $232 \mathrm{~b}$ \\
$10 \mathrm{~cm}$ & $316 \mathrm{a}$ \\
Mowing frequency & \\
Monthly & $320 \mathrm{~b}$ \\
Bi-monthly & $232 \mathrm{c}$ \\
Tri-monthly & $196 \mathrm{c}$ \\
lx at start of season & $392 \mathrm{a}$ \\
1x at end of season & $228 \mathrm{c}$ \\
\hline
\end{tabular}

${ }^{1}$ Within either the mowing height (LSD=26) or mowing frequency $(L S D=41)$ treatments, means followed by the same letter are not different at $P<0.05$. 

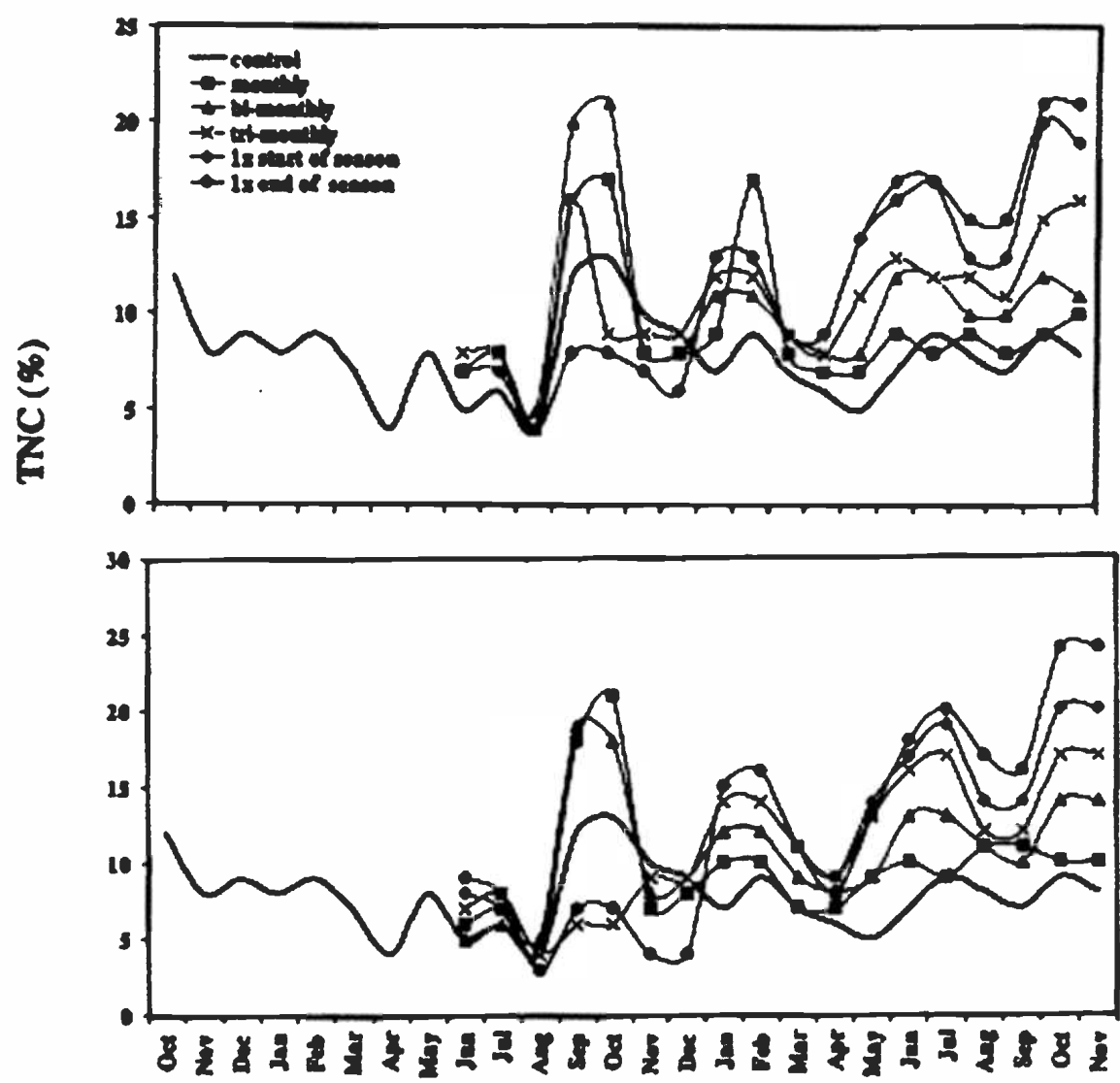

19

198

2000

\section{Date}

Fig. 2. Basal crown and stem base TNC trends in silver bluestem in the control and at the 5$\mathrm{cm}$ (top) and at the 10-cm (bottom) mowing height at different mowing frequencies.

tillers and allocate all available resources to their own growth. Under high stubble mowing, relatively larger parental tillers would always share resources with their daughter tillers, resulting in reduced tiller mortality and higher tiller recruitment.

Table 2. Mean tiller density (height $\mathrm{x}$ frequency interaction) for blue grama as subjected to different mowing heights and frequencies after 2 mowing seasons.

\begin{tabular}{lcc}
\hline \hline Mowing Treatment & \multicolumn{2}{c}{ Mowing height } \\
& $5 \mathrm{~cm}$ & $10 \mathrm{~cm}$ \\
\hline & \multicolumn{2}{c}{ (Tiller $\mathrm{m}^{-2}$ ) } \\
Non-mowing & \multicolumn{2}{c}{$292 \mathrm{a}$} \\
Mowing frequency & & \\
Monthly & $224 \mathrm{a}$ & $172 \mathrm{c}$ \\
Bi-monthly & $176 \mathrm{~b}$ & $268 \mathrm{~b}$ \\
Tri-monthly & $164 \mathrm{bc}$ & $180 \mathrm{c}$ \\
lx at start of season & $204 \mathrm{ab}$ & $168 \mathrm{c}$ \\
lx at end of season & $152 \mathrm{c}$ & $288 \mathrm{ab}$ \\
\hline
\end{tabular}

Within the $5 \mathrm{~cm}$ stubbie height among mowing frequencies, means $(L S D=24)$ with the same letter are not significant at $\mathrm{P}<0.05$.

${ }^{2}$ Within the $10 \mathrm{~cm}$ stubble height among mowing frequencies, means $(L S D=24)$ with the same letter are not significant at $\mathrm{P}<0.05$.

\section{Silver bluestem}

After 1 mowing season, plots mowed at the 5-cm stubble height produced fewer $(P$ $<0.05)$ tiller than the control. Plants mowed monthly produced the fewest $(\mathrm{P}<$ $0.05)$ tillers when compared to all other mowing frequency treatments (Table 3).

After 2 mowing seasons, mowed plots, regardless of mowing height, produced fewer tillers $(P<0.05)$ than non-mowed plots. Plants mowed tri-monthly produced the lowest $(P<0.05)$ number of tillers compared to the other mowing frequencies, presumably due to the timing of mowing relative to the phenological stage of the plant (Table 3). Similar trends were also observed in blue grama at either 5- or $10-\mathrm{cm}$ mowing treatment (Table 2). The higher rates of floral initiation and differentiation occurred in August when trimonthly mowing was applied. Vogel and Bugstad (1968) showed that clipping between floral initiation and anthesis sharply reduced tillering in several grasses. This was largely attributed to disruption of normal photosynthesis. August was also a period when TNC concentratio was relatively low (Fig.1 and 2). Whe Lolium perenne plants were defoliated, th limited TNC was preferably used to gror new leaf laminae and enhance photosyn thetic capacity rather than to initiate nev tillers (Donaghy and Fulkerson 1998 Higher rates of inflorescence developmer in August may have also slowed till recruitment by reducing assimilate avail ability for tiller growth due to intens competition from flowering (Colvill an Marshall 1984, Wan and Sosebee 1998).

Mowing x year interaction was detecte during the silver bluestem study. Plan mowed at either stubble height produce fewer $(P<0.05)$ tillers after 2 mowin seasons than after 1 mowing season. $A$ mowing frequencies (except the monthl mowing) produced fewer $(\mathrm{P}<0.05)$ tiller after 2 mowing seasons than after 1 mow ing season (Table 3).

In contrast to blue grama, silve bluestem is more vulnerable to frequer mowing and 2 consecutive years mowin (Table 3). Blue grama is a sod-formin grass with compressed basal internod and numerous short vegetative shool when intensively defoliated over a length period of time (Dahl and Hyder 1977 Silver bluestem, by contrast, is a mil grass that produces many short bast internodes in the vegetative state, $b$ abundance of long shoots (flowerin culms) in the reproductive state (Soseb

Table 3. Mean tiller density for silver blueste as subjected to different mowing heights ar frequencies after 1 and $\mathbf{2}$ mowing seasons.

\begin{tabular}{lrr}
\hline \hline & \multicolumn{3}{c}{ Tiller Density } \\
Mowing Treatment & 1 season & 2 seasons \\
\hline Mowing height & \multicolumn{2}{c}{ (Tiller $\mathrm{m}^{-2}$ ) } \\
Non-mowed & $228 \mathrm{a}^{1}$ & $296 \mathrm{a}^{2}$ \\
& $\mathrm{~B}$ & $\mathrm{~A}$ \\
$5 \mathrm{~cm}$ & $198 \mathrm{~b}$ & $163 \mathrm{~b}$ \\
& $\mathrm{~A}$ & $\mathrm{~B}$ \\
$10 \mathrm{~cm}$ & $217 \mathrm{ab}$ & $166 \mathrm{~b}$ \\
& $\mathrm{~A}$ & $\mathrm{~B}$ \\
Mowing frequency & & \\
Monthly & $146 \mathrm{~b}$ & $156 \mathrm{~b}$ \\
& $\mathrm{~B}$ & $\mathrm{~B}$ \\
Bi-monthly & $224 \mathrm{a}$ & $196 \mathrm{a}$ \\
& $\mathrm{A}$ & $\mathrm{B}$ \\
Tri-monthly & $218 \mathrm{a}$ & $130 \mathrm{c}$ \\
& $\mathrm{A}$ & $\mathrm{B}$ \\
$1 \mathrm{x}$ at start of season & $232 \mathrm{a}$ & $192 \mathrm{a}$ \\
& $\mathrm{A}$ & $\mathrm{B}$ \\
$1 \mathrm{x}$ at end of season & $216 \mathrm{a}$ & $150 \mathrm{~b}$ \\
& $\mathrm{~A}$ & $\mathrm{~B}$ \\
\hline
\end{tabular}

Within columns, for either mowing height or mowi frequency treatments, means $(\mathrm{LSD}=18$ ) with the sas lowercase letter are not significant at $\mathrm{P}<0.05$.

${ }^{2}$ Within rows, for either mowing height or mowing if quency treatment, means ( $L S D=18$ ) with the sas uppercase letter are not different at $\mathrm{P}<0.05$. 
Table 4. Mean biomass of blue grama at different mowing heights and frequencies during 1999 and 2000

\begin{tabular}{ll}
\hline \hline Treatment & Biomass \\
\hline $\begin{array}{l}\text { Mowing height } \\
\text { Non-mowed }\end{array}$ & $1,712 \mathrm{a}^{1}$ \\
$5 \mathrm{~cm}$ & $1,508 \mathrm{~b}$ \\
$10 \mathrm{~cm}$ & $1,407 \mathrm{~b}$ \\
& \\
Mowing frequency & \\
Monthly & $1,381 \mathrm{a}$ \\
Bi-monthly & $1,534 \mathrm{a}$ \\
Tri-monthly & $1,470 \mathrm{a}$ \\
Ix at start of season & $1,548 \mathrm{a}$ \\
Ix at end of season & $1,352 \mathrm{a}$ \\
\hline
\end{tabular}

Within either the mowing height or mowing frequency treatment, means followed by the same letter are not different at $\mathrm{P}<0.05$.

et al. 2003). In these long shoots, growing points are elevated as internodes elongate. When the elevated apical meristem is removed by mowing, regrowth is limited to tiller recruitment from the axillary buds, which is a rather slow process. Therefore, blue grama can maintain a higher proportion of photosynthetic tissue (Dahl and Hyder 1977) relative to silver bluestem following defoliation, allowing it to recover faster than silver bluestem. This can be illustrated by the 2-year-average aboveground live biomass data of the 2 grasses. In blue grama, the non-mowed plots had only $18 \%$ more aboveground biomass than the mowed plots, but there was no difference in live biomass between the 5-cm and $10-\mathrm{cm}$ mowing treatments $(\mathrm{P}>0.05$, Table 4). Also, blue grama live biomass was not affected by mowing frequency ( $P$ $>0.05$, Table 4). In silver bluestem, the non-mowed plots had a live biomass that

Table 5. Mean biomass of silver bluestem at different mowing heights and frequencies during 1999 and 2000

\begin{tabular}{ll}
\hline \hline Treatment & Biomass \\
\hline Mowing height & $\left(\mathrm{kg} \mathrm{ha}^{-1}\right)$ \\
Non-mowed & $2,730 \mathrm{a}^{\mathrm{I}}$ \\
$5 \mathrm{~cm}$ & $1,663 \mathrm{c}$ \\
$10 \mathrm{~cm}$ & $1,953 \mathrm{~b}$ \\
& \\
Mowing frequency & $1,239 \mathrm{e}$ \\
Monthly & $1,700 \mathrm{c}$ \\
Bi-monthly & $1,508 \mathrm{~d}$ \\
Tri-monthly & $2,655 \mathrm{a}$ \\
Ix at start of season & $1,939 \mathrm{~b}$ \\
Ix at end of season &
\end{tabular}

Within either the mowing height or mowing frequency treatment, means followed by the same letter are not different at $\mathrm{P}<0.05$. was $40-60 \%$ greater $(P<0.05)$ than the mowed plots, and the $10-\mathrm{cm}$ mowing produced $17 \%$ more biomass than the $5-\mathrm{cm}$ mowing ( $\mathrm{P}<0.05$, Table 5 ). In silver bluestem, lowest biomass was recorded for the monthly mowing treatment (Table 5), which paralleled to the lower tiller densities for 1 and 2 mowing seasons (Table 3 ).

Although the TNC concentration in grass crown can provide some indication of plant carbon reserves, TNC level alone cannot accurately explain the energy reserves of the plant, the weight of plant materials has to be involved to determine the actual amount of TNC or TNC pools. When silver bluestem was subject to frequent mowing, not only its TNC concentration declined, but also its live biomass (Table 5), therefore, the decline in TNC level was magnified in terms of total amount of TNC available. Because of sharply reduced TNC pools under more frequent mowing, tiller growth in silver bluestem was significantly affected (Table $3)$. The TNC pools are directly related to the amount of photosynthetic tissue remaining following defoliation. Richards and Caldwell (1985) showed that over $90 \%$ of the carbohydrates used for regrowth originate in the remaining nondefoliated plant tissue, and it only takes 3 days of photosynthesis to replenish the depleted TNC reserves in grass crown. The fact that at $10-\mathrm{cm}$ stubble mowing, blue grama tiller density remained stable after 2 mowing seasons is probably attributed to its fairly constant live biomass, or photosynthetic tissue. After mowing for 2 consecutive years, the highest tiller densities were observed in the non-mowed controls in both grasses, suggesting the significant roles of the amount of photosynthetic tissue in tiller growth.

\section{Summary and Conclusion}

Carbohydrate concentrations increased as frequency of mowing decreased in both species, regardless of stubble height. Mowing did not have a consistent impact on blue grama tiller density, although the $10-\mathrm{cm}$ mowing bi-monthly and 1 time only at the end of season produced the higher tiller densities than other mowing treatments after 2 mowing seasons. Whereas, frequent mowing of silver bluestem adversely affected tiller number. Silver bluestem produced fewer tillers after 2 mowing seasons than after 1 mowing season, which suggests that intensive mowing during consecutive years will cause the demise of this species.
Growth habit and ability of plants to respond to defoliation should be considered when planning mowing strategies of highway rights-of-way. The sod-forming growth habit of blue grama can be maintained with frequent mowing, but $10-\mathrm{cm}$ mowing appears to be more suitable for tiller regrowth than $5-\mathrm{cm}$ mowing. While silver bluestem, a mid-seral, mid-grass could be sustained along roadsides by allowing rest periods between mowings to ensure regeneration. In both species, mowing in periods of rapid inflorescence development should be avoided, since it may reduce tiller regrowth and result in stand decline.

\section{Literature Cited}

Briske, D. D. and J. H. Richards. 1995. Plant responses to defoliation: A physiologic, morphologic and demographic evaluation, $\mathrm{p}$ 635-710. In: Bedunah, D. J., and R. E. Sosebee E. (eds.) Wildland Plants: Physiological ecology and developmental morphology. (lst ed.). Soc. Range Manage., Denver, Colo.

Butler, J. L. and D. D. Briske. 1988. Population structure and tiller demography of the bunchgrass Schizachyrium scoparium in response to herbivory. Oikos 51:306-312.

Buwai, M. and M. J. Trlica. 1977a. Defoliation effects on root weight and total non-structural carbohydrates on blue grama and western wheatgrass. Crop Sci. 17:15-17.

Buwai, M. and M. J. Trlica. 1977b. Multiple effects on herbage yield, vigor, and total nonstructural carbohydrates of five range species. J. Range Manage. 30:164-171.

Caraco, T. and C. Kelly. 1991. On the adaptive value of physiological integration in clonal plants. Ecol. 72:81-93.

Colvill, K. E. and C. Marshall. 1984. Tiller dynamics and assimilate partitioning in Lolium perenne with particular reference to flowering. Ann. Appl. Biol. 104:543-557.

Coyne, P. I., M. J. Trlica, and C. E. Owensby. 1995. Carbon and nitrogen dynamics in range plants, p. 59-167. In, D. J. Bedunah, and R. E. Sosebee (eds.) Wildland Plants: Physiological ecology and developmental morphology. (1st.ed). Soc. For Range Manage., Denver, Colo.

Dahl, B. E. and D. N. Hyder. 1977. Developmental morphology and management implications, p. 257-290. In: R. E. Sosebee (ed.) Rangeland plant physiology. Range Sci. Series No. 4. Soc. Range Mange. Denver, Colo.

Donaghy, D. J. and W. J. Fulkerson. 1998. Priority for allocation of water-soluble carbohadrate reserves during regrowth of Lolium perenne. Grass Forage 53:211-218.

Eneboe, E. J., B. F. Sowell, R. K. Heitschmidt, M. G. Karl, and M. R. Haferkamp. 2002. Drought and grazing: IV. Blue grama and western wheatgrass. J. Range Manage. 55:73-79. 
Forwood, J. R. and M. M. Magai. 1992. Clipping frequency and intensity effects on big bluestem yield, quality, and persistence. J. Range Manage. 45:554-559.

Hyder, D. N. 1972. Defoliation in relation to vegetative growth, p. 304-317. In: V. B. Younger and C. M. McKell (eds.) Biology and utilization of grasses. Academic Press, New York.

Koos, W. M., L. A. Putnam, and W. D. Mitchell, 1966. Soil Survey of Crosby County, Texas. USDA. Series 1961. No. 36.

Menke, J. W. and M. J. Trlica. 1981. Carbohydrate reserve, phenology, and growth cycles of nine Colorado range species. J. Range Manage. 34:269-277.

Menke, J. W. and M. J. Trlica. 1983. Effects of single and sequential defoliations on the carbohydrate reserves of four range species. J. Range Manage. 36:70-74.
Mowery. I. C. and G. S. McKee. 1959. Soil survey of Lynn County, Texas. USDA. Series 1953. No. 3.

Murphy, R. P. 1958. Extraction of plant samples and the determination of total soluble carbohydrates. J. Sci. Food Agr. 9: 714-717.

Mullahey, J. J., S. S. Waller, and L. E. Moser. 1990. Defoliation effects on production and morphological development of little bluestem. J. Range Manage. 43:497-501.

Richards, J. H. and M. M. Caldwell. 1985. Soluble carbohydrates, concurrent photosynthesis and efficiency in regrowth following defoliation: A field study with Agropyron species. J. Appl. Ecol. 22:907-920.

Sosebee, E.R., D.B. Wester, J.C. Villalobos, C.M. Britten, C. Wan, and H. Nofal. 2003. How grasses grow-How plant growth relates to grazing management. (In Press). Second National Conference on Grazing Lands, Proc.
Vogel, W. G. and A. J. Bjugstad. 1968 Effects of clipping on yield and tillering of little bluestem, big bluestem and Indiangrass J. Range Manage. 21:136-140.

Wan, C. and R. E. Sosebee. 1998. Tillerin responses to red far-red light ratio during dif ferent phonological stages in Eragrosti curvula. Environ. Exp. Bot. 40:247-254.

Wan, C. and R. E. Sosebee. 2002. Tillet recruitment and mortality in the dryland bunchgrass Eragrostis curvula as affected by defoliation intensity. J. Arid Environ 51:577-585.

White, L. M. 1973. Carbohydrate reserves it grasses: A review. J. Range Manage 26:13-18. 